\title{
The organizing and empowerment of informal settlement in Marand city (Aghzamin Locality) \\ Sepideh LIVARJANI ${ }^{1}$, Zahed MASOUMI ${ }^{2}$
}

${ }^{1}$ M.A of regional planning, Islamic Azad University of Tehran, Central branch, Tehran,
Iran. Email: S.livarjani68@gmail.com
${ }^{2}$ M.A of urban planning, Islamic Azad University of Yazd, Yazd, Iran
Email: Zahed_masoumi@yahoo.com

\begin{abstract}
Informal settlement (outskirt habitation) is one of the phenomena that have been emerged pursuant to structural developments and occurrence of social- economic and formative problems and issues such as quick urbanism flow and unbridled rural migrations in many countries of the world especially third world nations. The present article tends to examine, identify, and analyze social- economic and formative structure of informal habitat (outskirt settlement) in Aghzamin Locality at Region 1 of Marand city. The methodology of this study is of surveying type but at the same time librarian (documentary) technique has been adapted as well. Type of this study is of applied one in terms of objective and it is descriptive- analytical type based on research nature. After analysis of the necessary variables listed in 148 questionnaire forms (sample size) which have been derived from total 744 participants (statistical population) out of heads of families residing in informal habitats of Aghzamin locality the results have been inferred in this essay. Research findings came from analysis on social- economic and formative parameters indicates that a direct relationship is visible between inadvertent social- economic and formative conditions in informal settlement of Aghzamin locality.
\end{abstract}

Keywords: Informal Settlement, Marand city, Social- economic and formative structure, Aghzamin locality, Empowerment.

\section{Introduction}

Today, hundred millions of world people particularly in developing countries live in unallowable and messy habitats under unfavorable economic- social, and ecologic conditions. At the beginning of $21^{\text {st }}$ century, more than $50 \%$ of total 6 billion people of the world are living in urban areas. On the other hand, statistics and figures signify worsening poverty conditions throughout the world. Under such circumstances, especially cities in third world countries are tragically converted into the places for accumulation of poverty and gradually a great number of the poor people are rushed into outskirts of cities where they encounter new problems caused by local conditions as well (Mohammadi et al, 2008). Informal habitation is the phenomenon of economic equality and poverty and on the other hand overlooking low-income strata in planning particularly in formative and urban housing planning that often appear at the fields of wealth concentration. Economic poverty and unequal geographic distribution and concentration of wealth in developing countries causes wide population migration from poverty outskirts to wealth centers in order to enjoy 
opportunities for employment, income, and further services and hope for better future. In this process, due to lack of potential for economic attractive opportunity through life in internal space of cities, migrants to cities are living around and suburbs of them by informal habitation (Sheikhi, 2006). On the other hand, informal habitation may create shelter for high percent of urban population in developing nations (Abbott, 2002).

Various policies and plans have been taken versus informal habitation in the world including those policies that cover wide range from compulsory demolition and withdrawal to construction of low-cost houses and social housing and land and services technique. All of the aforesaid techniques have not too succeeded because of various reasons such as exclusion of all of urban low-income strata and ignoring financial and economic solvency of low-income families. For this reason, empowerment strategy was suggested along with improvement or renovation of the existing environments at the second half of 1980s. A boosting trend has occurred hereafter in studies and design of modern strategies to solve the problem internally and based on development of local communities to link with development macro policies and throughout the country and to extend determination of scale for them. Human is deemed as basic development pivot in acknowledgement of empowerment strategies that should be taken with physical improvement and renovation of localities and developmental plans should be started by considering this axis (Shahidi, 2007).

Quick urbanism stream has been followed by informal habitation in our country during recent decades and this growing phenomenon has created a lot of social, economic, cultural, formative, and environmental problems in most of cities of Iran, particularly in metropolises. According to the existing statistics, about 8 million of people in Iran are living in this type of habitats and outskirts of cities or inside them (Sarrafi \& Mohammadi, 2005). Phenomenon of informal housing in Iran is not caused by imbalanced population distribution and flooding rush of migrations but it is mainly due to administrative problems including organizing of informal habitation thereby and by proper administration of them the conditions and grounds may be provided for national sustainable development (Kamal Athari, 2001).

Regarding subject of informal settlement before Islamic Revolution in Iran, the coercive and demolishing strategies and ignorance policies were taken to treat with this problem among different techniques; in other words, organizing policies were not mainly proposed inside habitats before the revolution, but it was tried to remove these habitats in cities by taking policies such as providing of low-cost housing where establishment of 13-Aban Locality (30 ${ }^{\text {th }}$ October) was of this type for displacement of slum-dwellers inside Tehran city (Bigdeli, 2004).

Marand city has not been also excluded from the given developments in various fields of country and it has been followed by changes in parallel with them. Today, these changes and developments are revealed in form of outskirt settlement and it necessitates to take needed measures for preparation of projects to the aforesaid zones as soon as possible so that we do not witness critical status in the given areas.

\section{Methodology}

With respect to special properties of the project and study of outskirt settlement, a combinatorial method (combination of primary and secondary technique and methods) will be adapted for data collection. In primary method, data and information are collected 
through field studies and surveys while in secondary method data and formation are gathered by documentary techniques and librarian studies as well as censuses. Thus, hybrid method will be employed at present research.

Type of study is of applied developmental one and method of study is descriptiveanalytical type. Method of data collection is of librarian and field study. Aghzamin locality in Marand city is the geographic limit and spatial zone of study. Research statistical population includes 240 families living in Aghzamin locality and sample size is calculated for this population by Cochran formula as follows:

$$
n=\frac{\frac{t^{2} \cdot P \cdot q}{d^{2}}}{1+\frac{1}{N}\left(\frac{t^{2} \cdot P \cdot q}{d^{2}}-1\right)}=148
$$

Then, appropriate strategies have been proposed for organizing and empowerment of informal habitation in Aghzamin locality.

\subsection{Research theoretical framework}

Outskirt settlement, informal habitation, slum-housing, temporary and unconventional habitats etc. are some of symbols for urban poverty that reveals their ugly face in housing sector. The adverse and unfavorable living conditions for millions of people of dwellers of cities where they are deprived from their human basic rights may require making serious efforts by various community strata, public and non- public authorities, planners, and experts of urban and regional problems thereby to prepare ground for sustainable development. It is a matter of fact that recognition of problem by scientific and logical techniques will be the first and foremost step taken for any type of planning and control. From this perspective, it is necessary to recognize and analyze subjects and to present definitions about the given subject. Several attitudes and theories have been posited about subject of informal habitats and way of exposure to them so that here it is briefly referred to them.

\subsection{Informal habitation}

The autonomous habitats have been defined by some terms such as informal housing and outskirt settlement etc. (Sorour \& Jafari, 2009). Informal habitation covers only the built shelters on the spot on the land owned by others at outskirt of city by its formative concept and some phrases have been used synonymously such as abnormal housing, built shelter for one night, and improvised houses totally (Hataminejad, 2004). Marshal Colinard says the informal habitation is an urban problem and feature and it is the main origin for delinquency and crime in different forms (Abdollahi, 2009). The informal or illegal habitation includes various conditions in terms of right of ownership, living conditions, density, security and progress levels, and rate of change (Huchzereyer, 2009: 271). These zones have emerged on the spot and even their spatial positions are not clear on the map (Ruther et al, 2002). 


\subsection{The attitudes regarding informal housing}

Ecologic approach: In this approach, social Darwinism has been adapted for cities silently and specific formation of cities has been attributed to a general normal system in freedom of imperialism (Shakooyee, 2000). Referring to cultural and racial exposures caused by migration, Park assumes this phenomenon as one of the reasons for realization of outskirt settlement (Rabani et al, 2006).

Approach of political economy of space: In parallel with imbalanced growth in cities, rate of inequality of incomes increases and structural imbalances are accelerated in community that results in appearance of urban outskirt dwellers. In this approach, reasons for emerging of different habitats are discussed and it is tried to involve in root of problem. This approach looks for problem- solving in change of the governing business structure, production, distribution, and consumption i.e. economic structure and finally it seeks for fundamental change in communities and thus the case or sectional instruction is not deemed as effective for this problem so that such solutions are assumed as palliative ones under best conditions and it may probably hide root of pain as well (Piran, 1995).

Liberal approach: Liberal approach is not involved in this fact (why informal habitats emerge) and the existing fact (emerging and developing of informal habitats) is assumed as compulsory and it is accepted as consequences of the existing world system as a whole; therefore, it is only sufficed with presentation of some solutions at different levels (Piran, 1995).

Non- liberal approach: Unlike liberal thinkers in 1960s and 1970s, another group of thinkers such as theorists of Dependence School in Latin America expresses that the dependent and exogenous model and dependent industrialization trend are followed by accelerated and heterogeneous urbanism and inequality of incomes will increase in parallel with imbalanced growth and structural imbalances are accelerated in the community (Haj Yousefi, 2002).

Neo-socialism approach: According to attitude of thinkers in socialist school, informal habitation and emerging of outskirt groups in urban communities of developing countries is due to performance of normal trend of conflict among work and capital and it is the coercive consequence of performance of the rules governing over capitalism economic system i.e. concentration and accumulation of capital, imbalanced economic growth, and occurrence of social conflicts and thus occurrence of social conflicts and problems will be inevitable in metropolises in discordant development trend of capitalism community including informal habitation (Haj Yousefi, 2002).

\subsection{General specifications of areas of informal habitation}

Unfavorable appearance: The most major global symbol of informal habitation is their unfavorable appearance that may bother human's feeling, consciousness, and eyes where buildings have been demolished and worn. Routes and passages are labyrinth with narrowed width and there is not usually access route for rescue vehicles such as firefighting, emergencies, and police upon occurrence of accidents and risks (Masoudifar, 2006).

Low-quality of healthcare, welfare, servicing, and educational facilities: Number of schools and educational centers is usually lower than standard in these localities and there 
is no welfare- servicing center such as park, green space, cinema, firefighting station, and cultural center etc.

Expansion of household dimension and low income: The outskirt zones usually include higher population growth rate compared to other urban points and this stems from young structure of population in these localities and it is led to lower income per capita and thus poverty and malnutrition among them.

Young demographic structure and high unemployment rate in these areas: Whereas the majority of inhabitants in informal settlements are the youths who lack adequate scientific and professional skills and expertise and for this reason they migrate to cities to earn further facilities and income but they are settled in these areas because of lesser numbers of these localities (Sheidayee, 2009).

Presence of specific micro-cultures of small zones (Masoudifar, 2006)

Similarly, according to a report from human habitat center of UN, urban slums are defined as residential spaces that lack five key elements:

1) Access to healthy water

2) Wastewater disposal system

3) Security and right of possession

4) Quality and durability of construction

5) Adequate living space (UN-Habitat, 2005).

6)

\subsection{Empowerment}

Empowerment denotes developing assets and potentials of poor people for participation, haggling, effect, control, and preservation of responsive institutes which may influence in their lives (Narayan, 2002). This strategy relies on approach for removal of poverty and human-centered sustainable development with focus on participation of citizens and urban administration (Friedman, 1992). What it deemed as central in this strategy is special focus on rise of income and removal of poverty from family so that for this purpose it is crucially important to provide occupational trainings and to improve skill in workforce and helping them to access sources and organizing and better marketing for their business, especially by mediation of non-public and local organizations (Komato, 2002). Empowerment is based on approach of removal of poverty and it advances in human-centered sustainable development with focus on participation of citizens and city (urban administration) (Khazraei, 2002: 60). Increase in sense of attachment to locality and suitable responsiveness of inhabitants to this question (Question of government's share, people's share) in organizing of locality is the objective for participation or civil empowerment (Khatam, 2002).

From other perspective, empowerment comprises of three general aspects as a whole concept. The first one is achieved within market empowerment framework and second aspect is political empowerment that is derived through administrative- executive decentralization, institutional and administrative reform, and employment of organization. Selection of Community- Based Organizations (CBOs) and Non- Governmental Organizations (NGOs) is deemed as market and community empowerment followed by political and executive barriers (Burgess et al, 1997: 144). Empowerment strategy is a part of wider topics regarding Urban Good Governance (Irandoost, 2007). Third aspect is local community empowerment that is followed by local and national governments for 
coordination and facilitation of efforts made by local community organizations (CBOs) and execution of their projects through principal methods (Burgess et al, 1997).

\subsection{Studied zone}

With over $3311.9 \mathrm{~km}^{2}$ surface area, Marand city includes $7.1 \%$ of total areas of Eastern Azerbaijan Province and it is situated at northwest of this province and located within geographic coordinates $\left(38^{\circ}, 18^{\prime}-38^{\circ}, 52^{\prime}\right.$ northern latitude and $46^{\circ}, 20^{\prime}-45^{\circ}, 12^{\prime}$ eastern longitude) compared to Greenwich Meridian. This city is located on $1540 \mathrm{~m}$ higher than free sea level in average and it is limited from north to Jolfa city, to Shabestar city from south, to Ahar city from east, and to Western Azerbaijan Province at west and it is shared longer political border with Shabestar city at south among them.

There are three main zones of informal habitation (outskirt settlement) throughout Marand city that is normally called under titles of Aghzamin, Sardar Melli, and Mehrakhor. Zone 1 (Aghzamin locality) includes 4 areas. The Zone 1 of organizing project comprises of eastern and southeastern areas of Marand city where Zone 1 of informal habitation is placed jointly at Regions 3 and 4 and Localities Nos. 6 and 7 in area of detailed project.

From total 316.24 hectares of informal habitation lands (outskirt settlement zone) in Marand city, 53.99 hectares (i.e. 17.07\%) are located outside detailed project zone (Comprehensive Project) and the rest is situated inside legal city limit (Comprehensive Detailed Project) in farming lands, gardens, and arid and vacant farms. The areas of informal habitation include $22.53 \%$ of total surface of Marand city.

By identifying informal habitation (outskirt settlement) in Marand city based on the prepared map of urban textures of Marand city (approved map) in which three types of texture recognized for Marand, a texture has been given under title of marginal texture and at the same time those textures have been adjusted in status quo and by means of information from relevant officials and based on field visit.

Table 1: Wideness of regions and areas within limit of informal habitation (outskirt localities)

\begin{tabular}{|c|c|c|c|c|c|c|c|}
\hline \multirow[t]{2}{*}{ Region } & \multirow[t]{2}{*}{ Area } & \multicolumn{2}{|c|}{$\begin{array}{l}\text { Inside limit of } \\
\text { detailed project }\end{array}$} & \multicolumn{2}{|c|}{$\begin{array}{l}\text { Outside limit of } \\
\text { detailed project }\end{array}$} & \multicolumn{2}{|c|}{$\begin{array}{c}\text { Total limit of informal } \\
\text { settlement }\end{array}$} \\
\hline & & Surface are & $\begin{array}{c}\text { Perce } \\
\text { nt }\end{array}$ & Surface area & Percent & Surface area & Percent \\
\hline \multirow{4}{*}{1} & $1-1$ & 132847 & \begin{tabular}{l|l}
4.20 &
\end{tabular} & - & - & 132847 & 4.20 \\
\hline & $1-2$ & 453657 & 14.35 & - & - & 453657 & 14.35 \\
\hline & $1-3$ & 570763 & 18.05 & - & - & 570763 & 18.05 \\
\hline & $\overline{1-4}$ & 325858 & 10.31 & - & - & 325858 & 10.31 \\
\hline \multicolumn{2}{|c|}{ Total of region 1} & 1483134 & \begin{tabular}{l|l}
46.91 \\
\end{tabular} & - & - & 1483134 & 46.91 \\
\hline \multirow[t]{2}{*}{2} & $2-1$ & 341134 & 10.79 & 129612 & 4.10 & 470746 & 14.89 \\
\hline & $2-2$ & 573329 & 18.14 & - & - & 573329 & 18.14 \\
\hline \multicolumn{2}{|c|}{ Total of region 2} & 914463 & 28.93 & 129612 & 4.10 & 1044075 & 33.03 \\
\hline \multirow[t]{2}{*}{3} & \begin{tabular}{|l|}
$3-1$ \\
\end{tabular} & 143342 & 4.53 & 168164 & 5.32 & 311506 & 9.85 \\
\hline & $3-2$ & 80542 & 2.55 & 242150 & 7.66 & 322692 & 10.21 \\
\hline \multicolumn{2}{|c|}{ Total of region 3} & 223884 & 7.08 & 410314 & 12.98 & 634198 & 20.06 \\
\hline \multicolumn{2}{|c|}{ Sum } & 2621472 & 82.92 & 539926 & 17.08 & 3161398 & 100 \\
\hline
\end{tabular}

Source: Authors 
Map (1): Geographic situation of zone of Aghzamin locality in Marand city

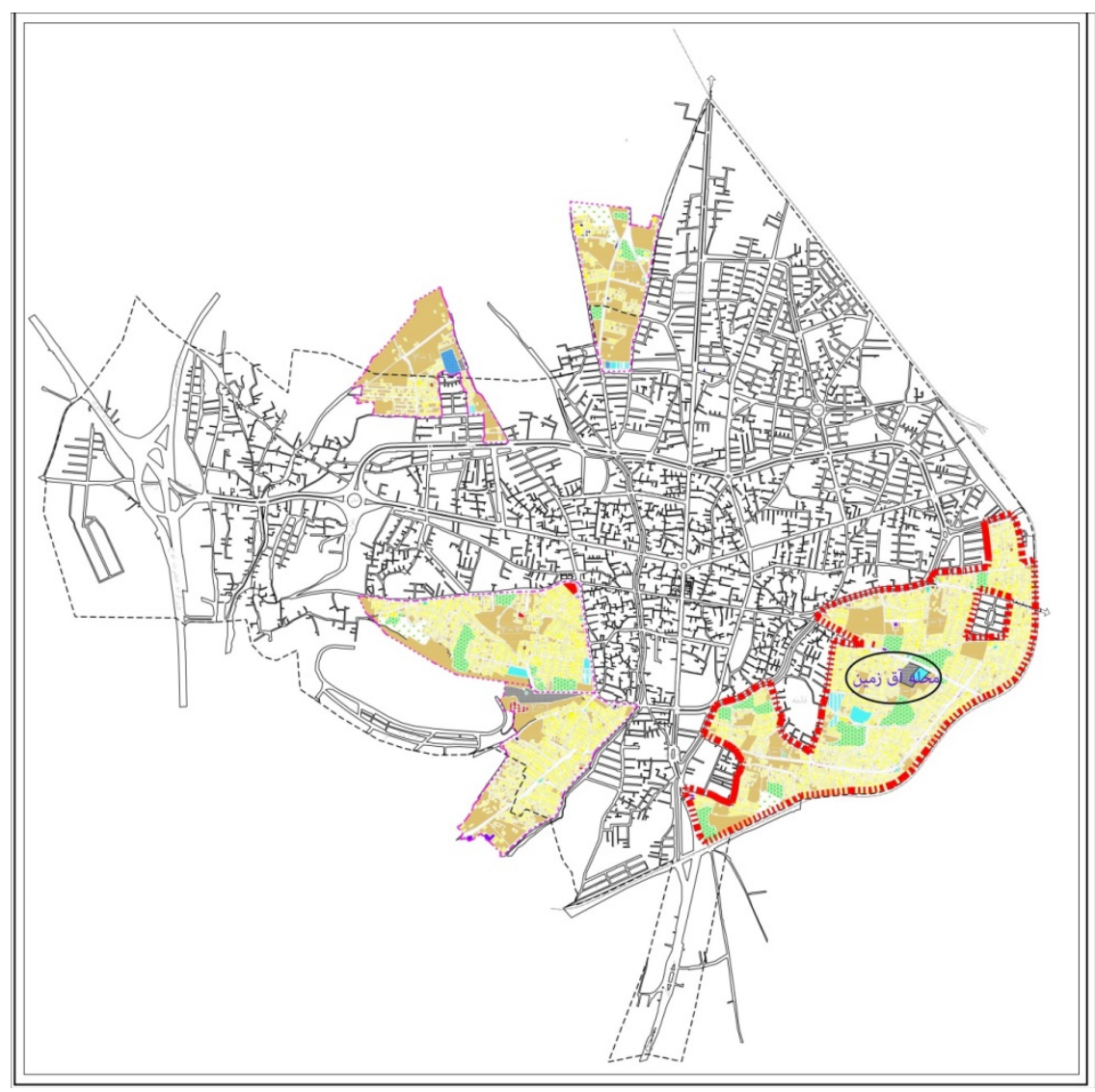

Source: Authors

\section{Research findings}

\subsection{Analysis on general economic features of Aghzamin locality}

1- Number and percent of employed group and ratio of employed group in major activity sectors

In terms of distribution of employees in major economic sectors, we observe activity and business for more than 59\% of employed group are working in servicing sector. After servicing sector, industry and agriculture sectors are ranked at subsequent positions with $37.07 \%$ and $3.09 \%$ respectively. 
Table 2: Number and percent of active employed population of Aghzamin locality of Marand separately based on major activity sectors

\begin{tabular}{|c|c|c|c|c|c|}
\hline $\begin{array}{l}\text { Major } \\
\text { activity } \\
\text { sectors }\end{array}$ & Major activity groups & \multicolumn{2}{|c|}{$\begin{array}{l}\text { Number of } \\
\text { employees }\end{array}$} & \multicolumn{2}{|c|}{$\begin{array}{l}\text { Percent of } \\
\text { employees }\end{array}$} \\
\hline \multirow[t]{3}{*}{ Agriculture } & Farming and gardening & 7 & \multirow{3}{*}{8} & 2.70 & \multirow{3}{*}{3.09} \\
\hline & Animal husbandry & 1 & & 0.39 & \\
\hline & $\begin{array}{l}\text { Fishing, aviculture and } \\
\text { apiculture }\end{array}$ & 0 & & 0.00 & \\
\hline \multirow{4}{*}{ Industry } & Industry & 63 & \multirow{4}{*}{96} & 24.32 & \multirow{4}{*}{37.07} \\
\hline & Construction & 33 & & 12.74 & \\
\hline & Water, electricity and gas & 0 & & 0.00 & \\
\hline & Mine extraction & 0 & & 0.00 & \\
\hline \multirow[t]{5}{*}{ Services } & $\begin{array}{l}\text { Wholesaling, retailing and } \\
\text { restaurant }\end{array}$ & 27 & \multirow{5}{*}{155} & 10.42 & \multirow{5}{*}{59.84} \\
\hline & $\begin{array}{c}\text { Transportation- } \\
\text { communications, and } \\
\text { warehousing }\end{array}$ & 4 & & 1.54 & \\
\hline & $\begin{array}{c}\text { Financial services, } \\
\text { insurance, real estate, legal } \\
\text { and commercial }\end{array}$ & 6 & & 2.32 & \\
\hline & $\begin{array}{c}\text { Public, social, and personal } \\
\text { services }\end{array}$ & 50 & & 19.31 & \\
\hline & Non-classifiable activities & 68 & & 26.25 & \\
\hline & Sum & \multicolumn{2}{|c|}{259} & \multicolumn{2}{|c|}{100} \\
\hline
\end{tabular}

Source: Authors

\subsection{Income model and rate in Aghzamin locality}

The highest income of Aghzamin locality inhabitants belongs to second class with $22.30 \%$. Income row (5-7 million Rials) is placed at next rank so that this income belongs to $20.95 \%$ of inhabitants i.e. about one fifth of total inhabitants and their income is placed at this group. Generally, about a half of (49.33\%) of income for inhabitants in the aforesaid locality is equal and/ or less than 7 million Rials. Only 1/6 (one sixth) of population in these areas have income higher than 13 million Rials and this rate is small compared to total region.

In terms of household costs, it can be implied that they adjust costs with their income. Difference among income and cost includes little percent in comparison therefore the second row has allocated the highest income (24.32\%) in this region similar to income. 
Table 3: Rate of income and cost of families in Zone 1 at Marand city

\begin{tabular}{|c|c|c|c|c|c|c|}
\hline Row & $\begin{array}{c}\text { Income } \\
\text { (thousand Rials) }\end{array}$ & Quantity & Percent & $\begin{array}{c}\text { Cost (thousand } \\
\text { Rials) }\end{array}$ & $\begin{array}{c}\text { Quanti } \\
\text { ty }\end{array}$ & Percent \\
\hline $\mathbf{1}$ & $\begin{array}{c}3 \text { million Rials } \\
\text { and lesser }\end{array}$ & 9 & 6.08 & $\begin{array}{c}3 \text { million Rials } \\
\text { and lesser }\end{array}$ & 8 & 5.41 \\
\hline $\mathbf{2}$ & $3-5$ million Rials & 33 & 22.30 & $3-5$ million Rials & 36 & 24.32 \\
\hline $\mathbf{3}$ & $5-7$ million Rials & 31 & 20.95 & $5-7$ million Rials & 32 & 21.62 \\
\hline $\mathbf{4}$ & $7-9$ million Rials & 20 & 13.51 & $7-9$ million Rials & 18 & 12.16 \\
\hline $\mathbf{5}$ & $9-11$ million Rials & 9 & 6.08 & $9-11$ million Rials & 10 & 6.76 \\
\hline $\mathbf{6}$ & $\begin{array}{c}11-13 \text { million } \\
\text { Rials }\end{array}$ & 21 & 14.19 & $\begin{array}{c}11-13 \text { million } \\
\text { Rials }\end{array}$ & 24 & 16.22 \\
\hline $\mathbf{7}$ & $\begin{array}{c}13 \text { million Rials } \\
\text { and higher }\end{array}$ & 25 & 16.89 & $\begin{array}{c}13 \text { million Rials } \\
\text { and higher }\end{array}$ & 20 & 15.13 \\
\hline
\end{tabular}

Source: Authors

\subsection{Analysis on general social characteristics in Aghzamin locality}

1- Birthplace of heads of families in Aghzamin locality

For more than $46 \%$ of heads of families, their birthplace is outside Marand throughout Aghzamin locality and approximately 38\% of them were born in Marand city and the rest ones have been born in Marand area.

Table 4: Birthplace of family head in areas and Zone 1 of Marand outskirt

\begin{tabular}{|c|c|c|c|c|c|c|c|c|c|c|}
\hline \multirow{3}{*}{$\begin{array}{c}\text { Aghza } \\
\text { min }\end{array}$} & \multicolumn{2}{|c|}{ Marand } & \multicolumn{4}{|c|}{ Marand cities } & \multicolumn{2}{c|}{$\begin{array}{c}\text { Outside } \\
\text { Marand }\end{array}$} & \multicolumn{2}{c|}{ Total } \\
\cline { 2 - 10 } locality & $\begin{array}{c}\text { Quant } \\
\text { ity }\end{array}$ & $\begin{array}{c}\text { Perce } \\
\text { nt }\end{array}$ & $\begin{array}{c}\text { Quant } \\
\text { ity }\end{array}$ & $\begin{array}{c}\text { Perce } \\
\text { nt }\end{array}$ & $\begin{array}{c}\text { Quant } \\
\text { ity }\end{array}$ & $\begin{array}{c}\text { Perce } \\
\text { nt }\end{array}$ & $\begin{array}{c}\text { Quant } \\
\text { ity }\end{array}$ & $\begin{array}{c}\text { Perce } \\
\text { nt }\end{array}$ & $\begin{array}{c}\text { Quant } \\
\text { ity }\end{array}$ & $\begin{array}{c}\text { Perce } \\
\text { nt }\end{array}$ \\
\cline { 2 - 11 } & 23 & 15.54 & 1 & 0.68 & 55 & 37.16 & 46.62 & 69 & 148 & 100 \\
\hline
\end{tabular}

Source: Authors

\subsection{The reasons for selection of Aghzamin locality for habitation by families}

The low-cost land is the main factor for settlement of most of people at Zone 1 (Aghzamin locality) so that $49.32 \%$ of inhabitants are living there. Along with above factors, one can refer to some other factors such as presence of business and employment in Marand city, absence of facilities in village, existing acquainted persons of family in this city and their relationship and presence of facilities in this city where the aforesaid factors are in fact the foremost factors for families to select this informal zone at Marand city. 
Table 5: The reasons for selection of Aghzamin locality for settlement by families

\begin{tabular}{|c|c|c|c|c|c|c|c|c|c|c|c|}
\hline \multirow{2}{*}{$\begin{array}{c}\text { Region } \\
1\end{array}$} & \multicolumn{11}{|c|}{ Reasons for selection of this locality } \\
\hline & هُّه & 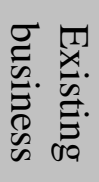 & 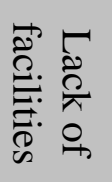 & $\stackrel{\substack{D \\
D}}{\stackrel{D}{\mathscr{D}}}$ & 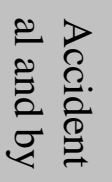 & 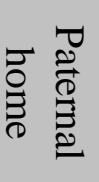 & 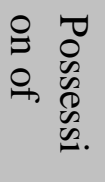 & 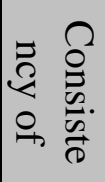 & 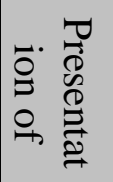 & 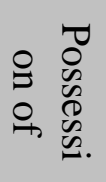 & 泀 \\
\hline Quantity & 73 & 8 & 20 & 17 & 19 & 5 & 2 & 2 & 2 & 0 & 148 \\
\hline Percent & 49.32 & 5.41 & 13.51 & 11.49 & 12.84 & 3.38 & 1.35 & 1.35 & 1.35 & 0.00 & 100 \\
\hline
\end{tabular}

Source: Authors

\subsection{Determination of literacy and education level in Aghzamin locality}

We observe $79.69 \%$ literacy rate among inhabitants in Aghzamin locality and only $20.31 \%$ of them are illiterate. We witness higher rate of education level in primary education with $21.73 \%$ at this region. The high rate of education at high school diploma is one of the other noticeable points that can be mentioned so that students in high school diploma level include $20.88 \%$ of literates in this region.

Table 6: The level of education in total families in region 1

\begin{tabular}{|c|c|c|c|}
\hline Education level & Illiterate & Literate & Total \\
\hline Quantity & 143 & 561 & 704 \\
\hline Percent & 20.31 & 79.69 & 100.00 \\
\hline
\end{tabular}

Source: Authors

Table 7: Distribution of major educational groups in total families at Aghzamin locality

\begin{tabular}{|c|c|c|c|c|c|c|c|c|c|c|}
\hline $\begin{array}{c}\text { Educati } \\
\text { on } \\
\text { degree }\end{array}$ & $\begin{array}{c}\text { Illitera } \\
\text { te }\end{array}$ & $\begin{array}{c}\text { Prima } \\
\text { ry }\end{array}$ & $\begin{array}{c}\text { seconda } \\
\text { ry }\end{array}$ & $\begin{array}{c}\text { High } \\
\text { scho } \\
\text { ol }\end{array}$ & $\begin{array}{c}\text { Diplo } \\
\text { ma }\end{array}$ & AA & BA & $\begin{array}{c}\text { M } \\
\text { A }\end{array}$ & $\begin{array}{c}\text { Ph } \\
\text { D }\end{array}$ & Total \\
\hline $\begin{array}{c}\text { Quantit } \\
\text { y }\end{array}$ & 143 & 153 & 130 & 68 & 147 & 23 & 37 & 3 & 0 & 704 \\
\hline Percent & 20.31 & 21.73 & 18.47 & 9.66 & 20.88 & $\begin{array}{c}3.2 \\
7\end{array}$ & $\begin{array}{c}5.2 \\
6\end{array}$ & $\begin{array}{c}0.4 \\
3\end{array}$ & $\begin{array}{c}0.0 \\
0\end{array}$ & $\begin{array}{c}100.0 \\
0\end{array}$ \\
\hline
\end{tabular}

Source: Authors

\subsection{Analysis of total formative features of Aghzamin locality}

1- Analysis of construction materials

Regarding analysis of construction materials in Aghzamin locality, the maximum percent of used construction materials in buildings are related to iron and brick (83.10\%) and then brick and wood have devoted the highest rate of construction materials in this region. 
Table 8: Determination of type of materials used in buildings at Aghzamin locality

\begin{tabular}{|c|c|c|c|c|c|c|c|}
\hline Materials & \multicolumn{7}{|c|}{ Aghzamin locality } \\
\cline { 2 - 8 } & $\begin{array}{c}\text { Metallic } \\
\text { structure }\end{array}$ & $\begin{array}{c}\text { Concrete } \\
\text { structure }\end{array}$ & $\begin{array}{c}\text { Iron and } \\
\text { brick }\end{array}$ & $\begin{array}{c}\text { Brick } \\
\text { and } \\
\text { wood }\end{array}$ & $\begin{array}{c}\text { Adobe } \\
\text { and } \\
\text { wood }\end{array}$ & Others & Total \\
\hline Quantity & 2 & 2 & 123 & 13 & 7 & 1 & 148 \\
\hline Percent & 1.35 & 1.35 & 83.10 & 8.80 & 4.70 & 0.70 & \\
\hline
\end{tabular}

Source: Authors

\subsection{Review on value of maintenance of buildings in informal settlement regions}

According to field studies and questionnaires, highest numbers of buildings in studied zones (65.54\%) are placed in group with maintenance potential while the lowest numbers of these buildings belong to demolished buildings in Aghzamin locality.

Table 9: Analysis of building in terms of potential for their maintenance in Aghzamin locality

\begin{tabular}{|c|c|c|c|c|c|}
\hline \multirow{2}{*}{$\begin{array}{c}\text { Value of } \\
\text { building }\end{array}$} & \multicolumn{5}{|c|}{ Aghzamin locality } \\
\cline { 2 - 6 } & Newly-built & Maintainable & Repaired & Demolished & Total \\
\hline Quantity & 22 & 97 & 26 & 3 & 148 \\
\hline Percent & 14.86 & 65.54 & 17.57 & 2.03 & 100 \\
\hline
\end{tabular}

Source: Authors

\section{Conclusion and suggestions}

The informal habitation is a type of lifestyle and as a geographic phenomenon it originates from human and environment relations. This type of living is the spatial manifestation of human unequal relations in access to living facilities and utilities at environmental scene.

Requests, requirements, and problems of inhabitants in Aghzamin locality at Marand city have been determined according to completion of questionnaires, field study, and interview. The review on problems and issues declared by locality inhabitants indicates different dimensions of them within social- cultural, economic, formative, environmental, and urbanism frameworks. The present research is intended to examine and analyze socialeconomic and formative structure of informal habitation in Aghzamin locality at Marand city. The following facts can be expressed by concluding from aforesaid parameters in this study:

Most of inhabitants in this locality have mentioned low-cost of land in this locality as the reason for selection of this place for settlement so that $49.32 \%$ of inhabitants expressed this fact. Analysis on this parameter signifies this point that most of inhabitants in Aghzamin locality have low income and costs in such a way that $51.35 \%$ of dwellers of this locality have monthly income less than 7 million Rials and they lack potential for buying of housing and lands that are benefitted from urban services and facilities therefore they have to roam to outskirt areas (according to field studies, birthplace of more than $46 \%$ of heads of families was located outside Marand and approximately 38\% of them have been also 
born in Marand city) and this has led to unauthorized constructions and low-quality buildings. As it mentioned in surveys about this issue as well, most of buildings in Aghzamin locality (65.56\%) are buildings with potential for maintenance but at final stage of useful life and brick and iron are some of the materials mainly used in them (83.10\%).

The other point which can be implied about the conducted study is that the low literacy level (20.31\% illiterates and $21.73 \%$ at primary literacy) also leads this class of society toward city outskirt and their informal settlement.

In the course of organizing Aghzamin locality in Marand city and thus preparation of ground for improvement of environmental conditions in this locality in sustainable form and by all-inclusive participation by inhabitants of Aghzamin locality in making decisions and local measures, some strategies and policies are suggested at macro, medium, and micro levels as follows:

- Improvement and enhancement of role of staffs and empowerment and organizing for informal habitation in administration of urban and servicing affairs at the areas of informal settlement

- Increase in production, direct supply, and improvement in production of handicrafts

- Equitable distribution of facilities especially in low-income inhabitant and outskirt areas

- Encouragement for internal and external investments in reconstruction of informal habitation zones

- Improvement of jobs at micro level

- Encouragement of domestic and foreign banks to invest for financing and providing of loans needed for informal habitation organizing project

- Optimal utilization from executive potentials of relevant and beneficiary organizations relating to informal habitation organizing project

- Rising level of social welfare and improvement in social- cultural conditions in outskirt inhabitant areas of Marand city

- Making effort for enhancement of cultural level and social insight of inhabitants

- Reducing rate of migration from rural areas to urban regions

- $\quad$ Rise of public partnership in informal habitation organizing project

- Increase in trust in cultural paradigm

- Change in negative subjectivity and attitude toward officials as decision-makers at high level as well as citizens regarding outskirt areas

\section{References}

1. Mohammadi, Yasser, Rahimian, Mehdi, Movahed Mohammadi, Hamid, Taraf Yalivi, Abdul Hassan (2008), Analysis of outskirt settlement challenges in Koohdasht city, Lorestan province, Physiographical researches, vol. 66, pp. 85-98

2. Sheikhi, Mohammad (2006), Urban administration and autonomous habitats at urban macro zones

3. Abbott, john.2002, A method - based planning frame work for informal settlement

4. Upgrading, Habit intevuational.26

5. Shahidi, Akram, (autumn, 2007), 'Empowerment of local communities in informal settlement as a step toward urban stability', specialized quarterly of housing and revolution. IRI Housing Foundation, vol. 119 
6. Sarrafi, Mozaffar, Mohammadi, Alireza (2005), 'Formation and expansion of informal settlement: Reasons, challenges, and strategies', Quarterly of geology, vol. 11 (specific to geography), pp. 39-54

7. Athari, Kamal, (2001), Measurement of structural and institutional reasons for outskirt habitation in Iran

8. Bigdeli, D. (2004), Organizing of informal settlement (Case study: Fatemiyeh Locality in Zanjan city), MA thesis, University of Zanjan

9. Sorour, Rahim, Jafari, Farhad (2009), 'Analysis on urbanism trend and prospection of informal habitats at megalopolis zone of Tehran', scientific- research quarterly of Iranian Geography Association, 7 (23), pp. 77-93

10. Hataminejad, Hossein (2004), Informal settlement in megalopolis of Mashhad, Collection of essays about outskirt habitation and informal settlement, $1^{\text {st }}$ vol., Publication of University of Rehabilitation Sciences

11. Abdollahi, Ali (20090, Outskirt and outskirt settlement, conceptual processing

12. Huchzereyer, Marie, (2004): "from "contravention of laws" to "lack of rights": redefining the problem of informal settlements in South Africa", Habitat International 28.

13. Ruther, H., Hagai, M. M and Mtalo, E.G. (2002). Application of Snakes and Dynamic Programming Optimization in Modeling of Buildings in Informal Settlement Areas. ISPRS Journal of Photogrammetry and Remote Sensing.56 (2002): p 269-282.

14. Shakooyee, Hossein (2000), new attitudes in urban geography, Tehran: SAMT Pub

15. Rabani, Rasoul, Arizi, Foroogh Sadat (2006), Review of effective factors on formation of problem of outskirt settlement and the related consequences in Ahwaz city, Quarterly of geography and development, vol. 4, pp. 89-114

16. Piran, Parviz (autumn, 1995), 'Slum settlement in Iran’, Final part, Journal of politicaleconomic information, vol. 96-97

17. Haj Yousefi, Ali (2002), Phenomenon of urban outskirt settlement and its development process, Quarterly of seven cities, Civil activities and urban renovation organization, vol. 8

18. Masoudifar, R. (2006), Article of effect of outskirt settlement in occurrence of crime, first part 17/09/2006

19. UN-HABITAT (2005). Slums of the World: the Face of Urban Poverty in the New Millennium?

20. Friedmann, J., (1992), "The politics of alternative development", Cambridge, lackwell.

21. Komato, Mayomi (2002), Urban improvement and social partnership, Journal of seven cities, vol. 8, pp. 110-123

22. Khazraei, Farzin (2002), Empowerment in informal settlement, experience in Zahedan, Journal of seven city, $3^{\text {rd }}$ year, vol. 8

23. Khatam, Aazam (2002), People's share, government's share in projects for empowerment and renovation of locality, Journal of seven city, $3^{\text {rd }}$ year, vols. $9 \& 10$, Tehran

24. Irandoost, Kiomars (2007), Informal settlement a manifestation of urban unsustainable development, PhD thesis of urban geography, Faculty of Geography, Shahid Beheshti University 